\title{
PENGGUNAAN MEDIA ANIMASI UNTUK MENINGKATKAN HASIL BELAJAR SISWA PADA KOMPETENSI DASAR MENGGUNAKAN ALAT UKUR BERSKALA DI SMK
}

\author{
Faris Fauzi $^{1}$, Dedi Rohendi ${ }^{2}$, Yayat ${ }^{3}$ \\ Departemen Pendidikan Teknik Mesin, FPTK UPI \\ Jl. Dr. Setiabudhi No.207 Bandung 40154 \\ farisfauzi15@gmail.com
}

\begin{abstract}
ABSTRAK
Tujuan penelitian ini yaitu untuk mengetahui peningkatan hasil belajar siswa yang menggunakan media animasi dan respon siswa mengenai penggunaan media animasi pada proses pembelajaran. Metode penelitian yang digunakan yaitu kuasi eksperimen, dengan subjek penelitian 30 orang siswa dari dua kelas berbeda yaitu kelas X-A dan kelas X$\mathrm{B}$ yang diambil secara purposive sampling. Instrumen yang digunakan yaitu pretest, posttest, angket, dan lembar judgement. Hasil uji prasyarat untuk pretest, posttest menunjukkan kedua kelas homogen, dan berdistribusi normal. Hasil pengujian hipotesis pada kelas kontrol didapat rata-rata $\mathrm{N}-\mathrm{Gain}=0,19$ yang berada pada kategori rendah, sedangkan pada kelas eksperimen rata-rata $\mathrm{N}$-Gain $=0,58$ yang berada pada ketegori sedang. Uji hipotesis dengan menggunakan uji-t diperoleh pembelajaran dengan media animasi lebih baik daripada pembelajaran dengan handout, sedangkan untuk respon siswa didapat skor sebesar $87 \%$ yang berada pada kriteria tinggi.
\end{abstract}

Kata kunci: media animasi, alat peraga, hasil belajar

\section{PENDAHULUAN}

Sekolah Menengah Kejuruan (SMK) merupakan salah satu lembaga pendidikan formal yang tujuannya menyiapkan siswa menjadi calon tenaga kerja yang terampil dan produktif untuk bekerja pada bidangnya. Untuk bekerja, tidak hanya keterampilan yang dilihat tetapi siswa harus dibekali dengan kepribadian yang bermoral dan beretika. Dengan kata lain ada keseimbangan antara hardskill dan softskill yang dapat meningkatkan sikap profesional. SMK Negeri 12 Bandung merupakan sekolah menengah kejuruan dengan konsentrasi kejuruan pesawat udara. Jumlah siswa untuk setiap kelas sekitar 32 orang. Rasio antara anak dan alat ukur yaitu sekitar 1:11. Hal tersebut menyebabkan pada saat praktik sebagian besar siswa sering kesulitan dalam memahami materi yang sudah diberikan guru.

Imbas dari permasalahan yang telah dijelaskan, tidak heran apabila hasil belajar siswa pada mata pelajaran mengukur dengan alat ukur masih banyak yang di bawah KKM. Hal ini ditunjukkan dengan data hasil ujian akhir semester (UAS) untuk standar kompetensi mengukur menggunakan alat ukur (Tabel 1).

\footnotetext{
${ }^{1}$ Mahasiswa Departemen Pendidikan Teknik Mesin FPTK UPI

${ }^{2}$ Dosen Departemen Pendidikan Teknik Mesin FPTK UPI

${ }^{3}$ Dosen Departemen Pendidikan Teknik Mesin FPTK UPI
} 
Tabel 1. Nilai Ujian Semester (US) mengukur menggunakan alat ukur

\begin{tabular}{|c|c|c|c|c|c|c|c|c|c|c|}
\hline \multirow{3}{*}{$\begin{array}{l}\text { Interval } \\
\text { Nilai }\end{array}$} & \multicolumn{8}{|c|}{ Kelas } & \multirow{2}{*}{\multicolumn{2}{|c|}{ Total }} \\
\hline & \multicolumn{2}{|c|}{ X PPU 1} & \multicolumn{2}{|c|}{ X PPU 2} & \multicolumn{2}{|c|}{ X PPU 3} & \multicolumn{2}{|c|}{ X PPU 4} & & \\
\hline & Jumlah & $\%$ & Jumlal & $\%$ & Jumlah & $\%$ & Jumlah & $\%$ & $\mathrm{Jml}$ & $\%$ \\
\hline$X>7,50$ & 6 & 15 & 0 & 0 & 3 & 6 & 0 & 0 & 9 & 7 \\
\hline $\begin{array}{l}0<X \leq \\
7,49\end{array}$ & 28 & 85 & 32 & 100 & 29 & 94 & 32 & 100 & 121 & 93 \\
\hline Jumlah & \multicolumn{2}{|l|}{34} & \multicolumn{2}{|c|}{32} & \multicolumn{2}{|l|}{32} & \multicolumn{2}{|c|}{32} & 130 & 100 \\
\hline
\end{tabular}

Siswa yang mampu mencapai KKM= 7,50 sebanyak 9 orang siswa (7\%) sedangkan yang nilainya masih di bawah KKM sebanyak 121 orang (93\%). Penyebab lain rendahnya hasil belajar siswa yaitu kurang menariknya proses pembelajaran yang dilaksanakan di kelas. Proses pembelajaran yang terlaksana di kelas masih menggunakan bantuan handout sebagai sumber bahan ajar, masih terdapat kompetensi yang harusnya anak tahu tetapi tidak didukung kondisi yang sebenarnya seperti langkah apa saja yang harus dilakukan sebelum melakukan, ketika melakukan dan sesudah melakukan proses pengukuran dengan menggunakan mikrometer luar.

Salah satu komponen yang mempengaruhi keberhasilan dalam proses pembelajaran adalah penggunaan media pembelajaran, baik itu berupa alat peraga ataupun media animasi. Media animasi yang dimaksud bisa berupa multimedia yang menarik siswa untuk belajar. Media merupakan salah satu komponen yang ada dalam kegiatan belajar mengajar. Kegiatan belajar mengajar melibatkan beberapa komponen yaitu guru (pendidik), peserta didik, tujuan pembelajaran, isi pembelajaran, metode mengajar, media dan evaluasi pembelajaran (Adrian, 2004). Pendapat tersebut kegiatan belajar tidak hanya melibatkan satu komponen saja, tetapi terdapat tujuh komponen yang harus dipenuhi agar kegiatan belajar mengajar terlaksana dengan efektif.

Alat peraga memang efektif digunakan pada proses pembelajaran, tetapi hanya dipakai selama proses kegiatan belajar berlangsung. Alat peraga adalah suatu alat yang dapat diserap oleh mata dan telinga dengan tujuan membantu guru agar proses belajar mengajar siswa lebih efektif dan efisien (Sudjana \& Rivai, 2003). Selain penggunaan alat peraga, seiring dengan perkembangan teknologi informasi dan komunikasi. Dapat pula digunakan media animasi untuk menanggulangi permasalahan keterbatasan sarana. Dengan media animasi siswa dapat belajar sendiri hanya dengan software yang diberikan. Kegiatan belajar mengajar akan lebih efektif dan 
mudah bila dibantu dengan sarana visual, di mana $11 \%$ dari yang dipelajari terjadi lewat indra pendengaran, sedangkan $83 \%$ lewat indra penglihatan (Rusman, 2012). Di samping itu, dikemukakan bahwa kita hanya dapat mengingat 20\% dari apa yang kita dengar, namun dapat mengingat $50 \%$ dari apa yang dilihat dan di dengar.

Penerapan media animasi di SMKN 12 Bandung dapat menjadi alternatif keterbatasan sarana untuk alat peraga yang tidak tersedia ataupun alat peraga dengan jumlah yang terbatas. Hal ini didukung dengan jumlah unit komputer yang tersedia. Untuk satu unit komputer dapat digunakan oleh dua orang siswa. Tujuan penelitian ini untuk mengetahui apakah peningkatan hasil belajar dan respon siswa pada pembelajaran yang menggunakan media animasi pada kompetensi dasar menggunakan alat ukur berskala untuk dimensi. Proses belajar merupakan proses psikologis yang terjadi di dalam diri seseorang oleh karena itu sukar diketahui dengan pasti bagaimana terjadinya. Belajar adalah setiap perubahan yang relatif menetap dalam tingkah laku yang terjadi sebagai suatu hasil dari latihan atau pengalaman (Purwanto, 1996). Belajar ialah suatu proses usaha yang dilakukan sesorang untuk memperoleh suatu perubahan tingkah laku sebagai hasil dari interaksi dengan lingkungannya (Slameto, 2003).

Perubahan ini menunjukkan kinerja (perilaku), berarti belajar itu menentukan semua keterampilan, pengetahuan, sikap dan nilai yang diperoleh individu (peserta didik). Dalam belajar dihasilkan berbagai macam tingkah laku yang berlainan seperti pengetahuan, sikap, keterampilan, kemampuan, informasi dan nilai. Berbagai macam tingkah laku inilah yang disebut kapabilas sebagai hasil belajar. Hasil belajar adalah kemampuan yang dimiliki peserta didik setelah ia menerima pengalaman belajarnya (Sudjana \& Rivai, 2003). Belajar sebagai suatu perubahan dalam kapabilas manusia (Sagala, 2005).

Pembelajaran dengan memanfaatkan unit komputer dapat menggantikan peran guru yang biasanya memberikan materi dengan metode ceramah. Menurut Rusman (2012:60) menyatakan bahwa pembelajaran berbasis multimedia adalah kegiatan pembelajaran yang memanfaatkan komputer untuk membuat dan menggabungkan teks, grafik, audio, gambar bergerak (video dan animasi) dengan menggabungkan link dan tool yang memungkinkan pemakai untuk melakukan navigasi, berinteraksi, berkreasi dan berkomunikasi.

Seperti yang telah dijelaskan sebelumnya, pembelajaran dengan basis multimedia dimaksudkan agar proses pembelajaran dibuat sangat menarik dan dapat berinteraksi antara 
media yang ditampilkan dengan operator pengguna media tersebut. Sehingga tujuan dari proses pembelajaran yang dilaksanakan dapat tersampaikan.

Penelitian sebelumnya mengenai penerapan media animasi yang telah diterapkan memberikan hasil positif terhadap hasil belajar siswa. Beberapa penelitian yang berkaitan dengan penggunaan media animasi dengan model simulasi untuk meningkatkan hasil belajar siswa telah banyak dilakukan. Metode penelitian yang digunakan adalah kuasi eksperimen. Hasil eksperimen menunjukan bahwa peningkatan hasil belajar pada kelas yang menggunakan multimedia animasi tiga dimensi lebih baik hasilnya.

\section{METODE PENELITIAN}

Metode yang digunakan dalam penelitian ini yaitu metode penelitian semu (quasi experiment). Untuk desain penelitian yang digunakan yaitu desain Nonequivalent Control Group Design. Metode penelitian semu didasarkan karena pada kenyataannya sulit untuk mendapatkan kelompok kontrol untuk penelitian.

Sampel yang digunakan dalam penelitian ini yaitu kelas $\mathrm{X}$, kelas X-A digunakan sebagai kelas kontrol dan kelas X-B digunakan sebagai kelas eksperimen. Penentuan sampel dengan menggunakan metode purposive sampling. Instrumen yang digunakan yaitu non-tes berupa lembar judgement dan angket respon siswa, dan tes berupa soal pretest dan posttest. Pengolahan data dilakukan uji validitas, reliabilitas, tingkat kesukaran, dan daya pembeda setelah itu pada sampel dilakukan uji homogenitas, normalitas, N-Gain dan pengujian hipotesis dengan uji-t.

\section{HASIL PENELITIAN}

Media animasi yang digunakan pada penelitian ini yaitu dengan model simulasi sebagai alat untuk menyampaikan materi pembelajaran. Fitur yang disajikan dalam media animasi ini diantaranya: penyajian materi dibagi dalam tiga pertemuan, animasi dari penyajian materi dan evaluasi untuk mengukur kemampuan siswa. Pada prinsipnya, pengembangan media animasi didasarkan pada pengembangan multimedia.

Tahap analisis yaitu melakukan analisis terhadap permasalahan yang dihadapi oleh guru selama proses penyampaian materi kepada siswa kemudian dicari solusi dari permasalahan tersebut.Analisis secara umum yaitu pada tahapan ini proses analisis dilakukan dengan cara 
melakukan pencarian materi yang dibutuhkan untuk media animasi. Kemudian dilakukan proses konsultasi dengan guru alat ukur mengenai penggunaan media dalam proses pembelajaran.Analisis pengguna yaitu objek yang menggunakan media animasi ini yaitu siswa kelas X Sekolah Menengah Kejuruan (SMK) Negeri 12 Bandung pada pelajaran basic skill dengan kompetensi dasar penggunaan alat ukur berskala untuk dimensi. Media animasi digunakan oleh siswa mempelajari materi mengenai alat ukur dan guru hanya sebagai fasilitator dalam proses pembelajaran dengan menggunakan media animasi. Analisis perangkat keras (Hardware), yaitu perangkat keras yang digunakan dalam proses pengembangan media animasi ini yaitu dengan spesifikasi sebagai berikut: Prosessor Core $^{\mathrm{TM}}$ i3-M350, 2,30 GHz, RAM 4GB, Hardisk SATA 500 GB, VGA 1 GB 128 bit.

Media animasi dapat dioperasikan pada spesifikasi yang lebih rendah dari spesifikasi di atas. Analisis perangkat lunak (Software), yaitu yang digunakan untuk mendukung media animasi yang akan digunakan dalam proses pembelajaran diantaranya sebagai berikut: adobe flash yaitu merupakan aplikasi utama yang digunakan untuk membuat media animasi dengan penggunaan action script dan berbagai komponen pendukung lain yang terdapat dalam aplikasi. Adobe photoshop yaitu merupakan aplikasi pendukung yang digunakan untuk pembuatan dan pengubah gambar yang dapat membuat media animasi menjadi lebih menarik. Audacity yaitu merupakan aplikasi pendukung yang digunakan untuk merekam suara narator.

Langkah penelitian antara lain: tahap desain dengan indikator yang disajikan diantaranya: menyebutkan pengertian mikrometer sekrup, menyebutkan fungsi dan bagian utama mikrometer sekrup, memahami cara memegang dan mengatur dengan mikrometer sekrup, memahami jenis ketelitian mikrometer sekrup, memahami hal yang perlu diperhatikan dalam penggunaan mikrometer sekrup, memahami cara mengkalibrasi mikrometer sekrup, memahami cara pemeliharaan mikrometer sekrup, menggunakan mikrometer sekrup berdasarkan ketelitian

Tahap pengembangan yaitu memproduksi media animasi yang akan digunakan. Memproduksi media animasi ini terdapat beberapa tahapan, yaitu pembuatan antarmuka, pengkodean, dan tahapan pengetesan. Pembuatan antar muka di desain dengan tampilan menggabungkan warna yang cerah, animasi dan pemilihan tulisan yang membuat siswa tertarik dengan untuk menggunakan media animasi dalam proses pembelajaran. Berikut disajikan beberapa screenshoot tampilan antar muka media animasi yang dikembangkan. 


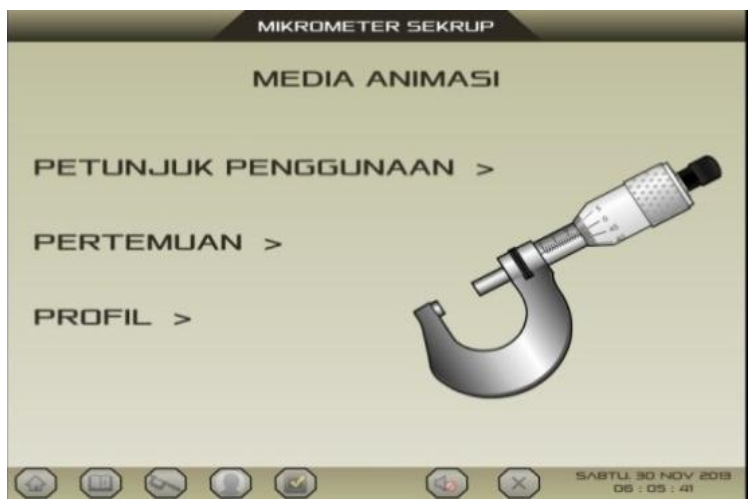

Gambar 1. Tampilan media animasi home

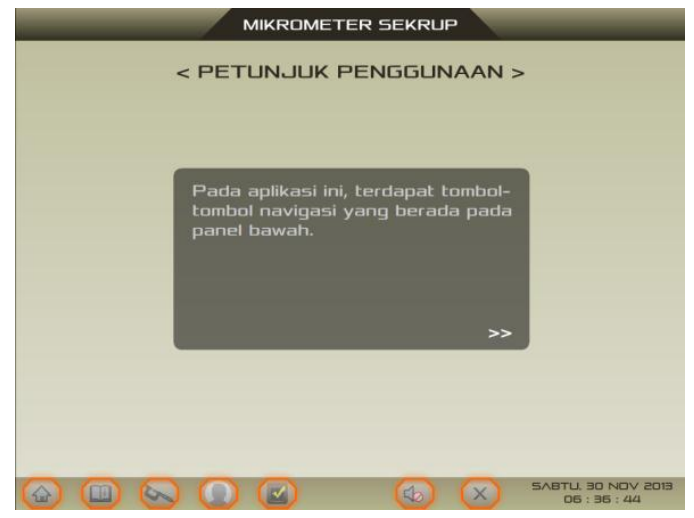

Gambar 2. Tampilan petunjuk penggunaan

Home (Gambar 1 dan 2) ada tiga pilihan menu yaitu petunjuk penggunaan, pertemuan, dan profil. Penyajian pada halaman ini dibuat menarik dengan animasi ketika tulisan muncul dan gambar mikrometer yang bergerak. dan fungsi dari setiap tombol tersebut. Tampilan penunjukan setiap tombol di desain dengan animasi panah bergerak ke tombol navigasi yang sedang dijelaskan.Tahap implementasi yaitu siswa sudah dapat menggunakan media animasi dalam proses pembelajaran. Dalam penggunaannya media animasi digunakan untuk membantu proses pembelajaran sebagai salah satu solusi mengatasi keterbatasan sarana. Penggunaan media animasi diterapkan di kelas eksperimen dengan alokasi waktu tiga kali pertemuan.

Tahap penilaian, yaitu menilai semua tahapan penelitian mengenai langkah-langkah dalam pengembangan media dapat disimpulkan kelebihan, kekurangan, kendala dan rekomendasi yaitu:

- Kelebihan, meliputi: pembelajaran dapat dilakukan dan berhenti kapan saja sesuai kehendak siswa dan media animasi bersifat student center yaitu siswa lebih aktif dalam proses pembelajaran.

- Kekurangan, meliputi: pertemuan selanjutnya pada media animasi akan terbuka apabila hasil evaluasi pada pertemuan sebelumnya mencapai skor 80. Tetapi apabila aplikasi di keluarkan maka pertemuan yang telah terbuka akan tertutup kembali. Kurangnya efek dalam animasi yang ditampilkan

- Kendala, antara lain: sulitnya mencari pengembangan materi mengenai mikrometer dan waktu pengembangan yang singkat membuat media animasi yang sedang dikembangkan belum mencapai hasil yang maksimal. 
- Rekomendasi, yaitu media animasi sebaiknya dibuat sistem penyimpanan sehingga apabila aplikasi keluar siswa tidak perlu mengulang dari awal. Media animasi sebaiknya mempunyai sistem untuk login. Animasi dibuat lebih smooth sehingga membuat proses pembelajaran lebih menarik.

Perhitungan pada data pretest dari setiap kelas kontrol ataupun kelas eksperimen dimaksudkan untuk menghitung homogenitas dari kelas yang digunakan dalam penelitian. Nilai rata-rata N-Gain digunakan untuk menghitung hipotesis dalam penelitian. Data rata-rata pretest, posttest dan N-Gain, ditunjukkan pada Tabel 2.

Tabel 2.Data hasil pretest, posttest, N-Gain

\begin{tabular}{lcccccc}
\hline \multirow{2}{*}{ Perhitungan } & \multicolumn{2}{c}{ Pretest } & \multicolumn{2}{c}{ Posttest } & \multicolumn{2}{c}{ N-Gain } \\
& Kontrol & Eksperimen & Kontrol & Eksperimen & Kontrol & Eksperimen \\
\hline Skor Terendah & 22,22 & 22,22 & 33.33 & 55,56 & 0 & 0,11 \\
Skor Tertinggi & 77,78 & 77,78 & 88,89 & 100 & 0,5 & 1 \\
Rata-Rata & 53.15 & 53,89 & 62,22 & 81,85 & 0,19 & 0,58 \\
Median & 10,36 & 10,1 & 10,67 & 14,9 & 0,18 & 0,59 \\
Modus & 10,56 & 11 & 11,17 & 14,83 & 0,19 & 0,61 \\
Std Deviasi & 3,18 & 3,39 & 2,54 & 2,02 & 0,14 & 0,34 \\
\hline
\end{tabular}

Rata-rata pada jenis data pretest antara kelas kontrol yaitu 53,15 dan kelas eksperimen yaitu 53,89. Hal ini menunjukkan kemampuan awal rata-rata siswa hampir sama. Setelah didapat data, kemudian dihitung homogenitas dari kedua kelas tersebut dengan menggunakan uji F. Hasil perhitungan didapat pada taraf nyata 5\% kedua kelas homogen. Kedua kelas tersebut dapat digunakan sebagai objek untuk penelitian. Data posttest menunjukkan nilai dan rata-rata kelas eksperimen yang menggunakan media animasi lebih besar apabila dibandingkan dengan hasil posttest kelas kontrol, proses pembelajaran pada kelas kontrol hanya menggunakan handout. Kelas eksperimen didapat skor tertinggi yaitu 100 dengan rata-rata 81,85 sedangkan untuk kelas kontrol skor tertinggi 88,89 dengan rata-rata 62,22.

Data menunjukkan rata-rata N-Gain untuk kelas eksperimen dan kelas kontrol, yaitu kelas eksperimen didapat rata-rata N-Gain 0,58 yang berada pada kategori sedang kemudian untuk kelas kontrol hanya 0,19 yang berada pada kategori rendah. Hasil data pretest, posttest, N-Gain dilakukan uji normalitas didapat seluruh kelompok data berdistribusi normal.

Pada penelitian ini, angket disebar di kelas eksperimen kepada siswa untuk mengetahui respon siswa mengenai proses pembelajaran dengan menggunakan media animasi. Hasil sebaran 
angket kepada 30 siswa di kelas eksperimen, diperoleh total skor 836. Hasil total skor diperoleh dengan menggunakan skala likert dengan rentang skor dari minimal 0 sampai skor maksimal 4 untuk setiap butir pernyataan. Jumlah maksimal skor angket dengan 8 butir pernyataan yang dibagikan ke 30 siswa yaitu 8x4×30=960. Jumlah skor yang didapat apabila dibandingkan dengan jumlah skor maksimal didapat skor dengan persentase $87 \%$. Skor tersebut apabila merujuk pada kriteria standar persentase jika bernilai $>75 \%$ termasuk kriteria tinggi, antara $61-75 \%$ termasuk kriteria sedang dan $<60 \%$ termasuk kriteria rendah (Arikunto, 2010:313). Persentase 87\% termasuk ke dalam kriteria tinggi.

\section{PEMBAHASAN}

Data yang didapat dari hasil penelitian yaitu berupa pretest dan posttest pada setiap kelas kontrol dan kelas eksperimen selanjutnya dilakukan perhitungan untuk menguji hipotesis pada penelitian ini. Proses perhitungan (Tabel 3) dilakukan kepada kelas kontrol dan kelas eksperimen.

Tabel 3. Hasil Pengujian Homogenitas, Normalitas dan Hipotesis

\begin{tabular}{|c|c|c|c|c|c|c|c|}
\hline \multirow[t]{2}{*}{ Data } & \multicolumn{3}{|c|}{$\begin{array}{l}\text { Uji Homogenitas } \\
\text { (Uji F) }\end{array}$} & \multicolumn{2}{|c|}{$\begin{array}{l}\text { Uji Normalitas } \\
\left(\chi^{2}\right) \text { dengan } \alpha=0,05\end{array}$} & \multicolumn{2}{|c|}{$\begin{array}{l}\text { Uji Hipotesis } \\
(\mathrm{t}-t e s t)\end{array}$} \\
\hline & p-value & & Kondisi & $p$-value & Kondisi & Nilai t & Kondisi \\
\hline \multirow[b]{2}{*}{ Pre-test } & \multirow{2}{*}{\multicolumn{2}{|c|}{$\begin{array}{l}\mathrm{F}_{\text {hitung }}= \\
0,89 \\
\mathrm{~F}_{\text {Tabel }}= \\
1,86 \\
F_{\text {hitung }}< \\
\mathrm{F}_{\text {Tabel }}\end{array}=$}} & \multirow[b]{2}{*}{$\begin{array}{l}\text { Dua Kelas } \\
\text { Homogen }\end{array}$} & $\begin{array}{l}\text { Kelas } \\
\text { Kontrol 7,3 } \\
\end{array}$ & Normal & \multirow{2}{*}{$\begin{array}{l}\mathrm{t}_{\text {hit }}=0,047 \\
\mathrm{t}_{\mathrm{tab}}=1,67 \\
-t_{\text {tab }} \\
\leq t_{\text {hitung }} \\
\leq t_{\text {tab }}\end{array}$} & \multirow[b]{2}{*}{$\begin{array}{l}\text { Ho } \\
\text { Diterima }\end{array}$} \\
\hline & & & & $\begin{array}{l}\text { Kelas } \\
\text { Eksperimen } \\
4,94\end{array}$ & Normal & & \\
\hline \multirow[b]{2}{*}{ Post-test } & \multirow{2}{*}{\multicolumn{2}{|c|}{$\begin{array}{l}\mathrm{F}_{\text {hitung }} \\
1,4 \\
\mathrm{~F}_{\text {Tabel }} \\
1,86 \\
F_{\text {hitung }}< \\
\mathrm{F}_{\text {Tabel }}\end{array}$}} & \multirow[b]{2}{*}{$\begin{array}{l}\text { Dua Kelas } \\
\text { Homogen }\end{array}$} & $\begin{array}{l}\text { Kelas Kontrol } \\
6,43 \\
\end{array}$ & Normal & \multirow[b]{2}{*}{$\begin{array}{l}\mathrm{t}_{\text {hit }}=2,54 \\
\mathrm{t}_{\mathrm{tab}}=1,67 \\
\mathrm{t}_{\text {hit }}>\mathrm{t}_{\mathrm{tab}}\end{array}$} & \multirow[b]{2}{*}{$\begin{array}{l}\mathrm{H}_{\mathrm{A}} \\
\text { Diterima }\end{array}$} \\
\hline & & & & $\begin{array}{l}\text { Kelas } \\
\text { Eksperimen } \\
1,49\end{array}$ & Normal & & \\
\hline \multirow[b]{2}{*}{ N-Gain } & & & & $\begin{array}{l}\text { Kelas Kontrol } \\
6,84\end{array}$ & Normal & \multirow{2}{*}{$\begin{array}{l}\mathrm{t}_{\text {hit }}=6,94 \\
\mathrm{t}_{\mathrm{tab}}=1,67 \\
\mathrm{t}_{\text {hit }}>\mathrm{t}_{\mathrm{tab}}\end{array}$} & \multirow{2}{*}{$\begin{array}{l}\mathrm{H}_{\mathrm{A}} \\
\text { Diterima }\end{array}$} \\
\hline & - & & & $\begin{array}{l}\text { Kelas } \\
\text { Eksperimen } \\
7,37 \\
\end{array}$ & Normal & & \\
\hline
\end{tabular}

Hasil perhitungan menunjukkan uji homogenitas didapat untuk data pretest dengan $\mathrm{F}_{\text {hitung }}=$ 0,89 yang berarti lebih kecil dari taraf signifikan yang ditetapkan yaitu $F_{\text {Tabel }}=1,86$. Hal ini 
menunjukkan apabila $F_{\text {hitung }}<\mathrm{F}_{\text {Tabel }}$ maka kelompok data dikatakan homogen.Data posttest dilakukan pengujian homogenitas pada kedua kelas. Dari hasil perhitungan didapat untuk data posttest dengan $\mathrm{F}_{\text {hitung }}=1,4$ yang berarti lebih kecil dari taraf signifikan yang ditetapkan yaitu $\mathrm{F}_{\text {Tabel }}=1,86$. Hal ini menunjukkan apabila $F_{\text {hitung }}<\mathrm{F}_{\text {Tabel }}$ maka kelompok data dikatakan homogen. Uji normalitas pada kelas kontrol dan kelas eksperimen untuk soal pretest, Dari hasil perhitungan didapat untuk data pretest dari kelas kontrol dengan $\chi^{2}=7,3$ dan kelas eksperimen dengan $\chi^{2}=4,94$. uji normalitas pada kelas kontrol dan kelas eksperimen untuk soal posttest. Hasil perhitungan didapat untuk data posttest dari kelas kontrol dengan $\chi^{2}=6,43$ dan kelas eksperimen dengan $\chi^{2}=1,49$. uji normalitas pada kelas kontrol dan kelas eksperimen untuk N-Gain. Hasil perhitungan didapat untuk data $N$-Gain dari kelas kontrol dengan $\chi^{2}=6,84$ dan kelas eksperimen dengan $\chi^{2}=7,37$. Dari ketiga kelompok data tersebut apabila $\chi_{\text {hitung }}^{2}$ lebih kecil dari taraf signifikan yang ditetapkan yaitu $\chi_{\text {tabel }}^{2}=7,81$. maka kedua kelas termasuk ke dalam distribusi normal.

Pengujian hipotesis untuk soal pretest. setelah dilakukan uji t dari data hasil pretest antara kelas kontrol dan kelas eksperimen didapat nilai $\mathrm{t}_{\text {hitung }}=0,047$ Nilai $\mathrm{t}_{\text {Tabel }}=1,67$ yang didapat karena $\mathrm{dk}=58$, maka dapat diambil kesimpulan untuk Ho diterima yaitu $-t_{\text {tab }}=-1,67 \leq$ $t_{\text {hitung }}=0,047 \leq t_{\text {tab }}=1,67$. Dilakukan uji $\mathrm{t}$ dari data hasil posttest didapat nilai $t_{\text {hitung }}=2,54$. Nilai $\mathrm{t}_{\text {Tabel }}=1,67$ yang didapat karena $\mathrm{dk}=58$, maka dapat disimpulkan bahwa $\mathrm{t}_{\text {hitung }}=2,54>$ $\mathrm{t}_{\text {Tabel }}=1,70$. Terakhir dilakukan uji hipotesis dengan menggunakan uji $\mathrm{t}$. Setelah dilakukan uji $\mathrm{t}$ dari data hasil $\mathrm{N}$-Gain didapat nilai $\mathrm{t}_{\text {hitung }}=6,94$. Nilai $\mathrm{t}_{\text {Tabel }}=1,67$ yang didapat karena $\mathrm{dk}=58$, maka dapat disimpulkan bahwa $\mathrm{t}_{\text {hitung }}=6,94>\mathrm{t}_{\text {Tabel }}=1,70$.

Setelah didapat hasil perhitungan dan analisis data yang telah dilakukan pada penelitian ini, menunjukkan bahwa adanya pengaruh terhadap hasil belajar siswa dalam penggunaan media animasi pada proses pembelajaran menggunakan alat ukur mikrometer. Peningkatan hasil belajar di data posttest pada kelas eksperimen yang menggunakan media animasi lebih baik apabila dibandingkan dengan proses pembelajaran yang hanya menggunakan handout. Tidak hanya dari data posttest, nilai rata-rata N-Gain menunjukkan kelas eksperimen yang menggunakan media animasi lebih baik dan meningkatkan hasil belajar siswa dibandingkan dengan kelas kontrol. Kemudian dibuktikan juga oleh uji hipotesis yang menunjukkan Ha diterima dengan kata lain media animasi dapat meningkatkan hasil belajar siswa dibandingkan dengan handout. Penggunaan media animasi lebih baik dibandingkan dengan penggunaan handout pada proses 
pembelajaran ditunjukkan juga oleh respon siswa yang berada pada kelas eksperimen. Respon siswa mengenai media animasi memberikan kemudahan untuk siswa dalam proses pembelajaran berada pada taraf tinggi yaitu 87\%. Rendahnya hasil belajar siswa pada kelas kontrol yang menggunakan handout sebagai media pembelajaran tidak terlepas dari peran handout itu sendiri yang hanya memberikan informasi secara satu arah.

\section{KESIMPULAN}

Kesimpulan dari penelitian ini yaitu peningkatan hasil belajar siswa pada pembelajaran kompetensi dasar menggunakan alat ukur berskala yang menggunakan media animasi lebih baik dibandingkan dengan yang menggunakan handout pada kompetensi dasar menggunakan alat ukur berskala. Respon siswa mengenai penggunaan media animasi pada pembelajaran kompetensi dasar menggunakan alat ukur berskala termasuk pada kategori tinggi.

\section{DAFTAR PUSTAKA}

Adrian. (2004). Metode Mengajar Berdasarkan Tipologi Belajar Siswa [Online]. Tersedia http://re-searchengines.com/art05-65.html [01 Agustus 2013].

Arikunto, S. (2010). Dasar-dasar Evaluasi Pendidikan. Jakarta: Bumi Aksara.

Purwanto, M.N. (1996). Psikologi Pendidikan. Bandung: P.T.Remaja Rosdakarya.

Rusman. (2012). Pembelajaran Berbasis Teknologi Informasi dan Komunikasi. Jakarta: Raja Grafindo Persada.

Sagala, S. (2005). Konsep dan Makna Pembelajaran. Bandung: Alfabeta

Slameto. (2003). Belajar Dan Faktor-Faktor Yang Mempengaruhinya. Jakarta: Rineka Cipta

Sudjana, N., dan Rivai, A. (2003). Teknologi Pengajaran. Bandung: Sinar Baru Algensindo 